\title{
Internationalisation Processes: an Analytical Framework
}

\author{
Sérgio Fernando Loureiro Rezende
}

\section{Resumo}

Este artigo contém uma proposta de análise de processos de internacionalização, entendidos como seqüências de modos de operação. Por sua vez, modo de operação é o arranjo institucional por meio do qual as firmas operam em mercados internacionais. A proposta de análise é baseada em conceitos da literatura de entrada em mercados internacionais, internacionalização e desenvolvimento de subsidiárias. Também são sugeridas três implicações para futuros estudos empíricos. Primeiro, acredita-se que processos de internacionalização podem ser analisados a partir de relacionamentos intra e interorganizacionais inseridos em contextos espaciais e temporais distintos. Segundo, a proposta de análise leva em consideração não somente processos incrementais, mas também processos de internacionalização descontínuos. Terceiro, propõe-se que processos de internacionalização são fenômenos sem fim e, portanto, devem abranger seqüências que ocorrem no mercado estrangeiro onde o modo de operação é inicialmente inserido, bem como mercados estrangeiros que são atingidos a partir do primeiro mercado estrangeiro.

Palavras-chaves: internacionalização; trajetórias internacionais; estratégias de entrada em mercados internacionais.

\begin{abstract}
In this article we propose a framework for analysing internationalisation processes, manifested through a sequence of servicing modes. A servicing turn is, in turn, the institutional arrangement whereby firms operate in foreign markets. The framework borrows conceptual notions from the literature on foreign market entry, internationalisation and subsidiary development. Three implications for empirical studies are subsequently suggested. First, it is argued that internationalisation processes should be analysed in light of intra and inter-organisational relationships embedded in distinct spatial and temporal contexts. Secondly, the framework takes into account not only incremental but also discontinuous internationalisation processes. Thirdly, it is proposed that internationalisation processes are endless phenomena and, therefore, should consider sequences of servicing modes that take place in the foreign market where the entry mode is originally embedded as well as in foreign markets reached from the initial host country.
\end{abstract}

Key words: internationalisation; international trajectories; foreign market entry strategies. 


\section{INTRODUCTION}

Internationalisation processes have received theoretical and empirical insights from studies based on the perspectives on foreign market entry (e.g. Anderson and Gatignon, 1986; Buckley and Casson, 1998a, 1998b; Dunning, 1998), on internationalisation (e.g. Johanson and Wiedersheim-Paul, 1975; Johanson and Vahlne, 1977, 1990) and, more recently, on subsidiary development (e.g. Birkinshaw, 1996, 1998; Birkinshaw and Hood, 1997). Traditionally, as these perspectives are grounded in different assumptions and provide rival explanations to internationalisation processes, scholars have largely discussed their incompatibilities rather than their potential interfaces (Bell and Young, 1998).

However, some researchers, such as Forsgren (1989), Forsgren and Johanson (1992) and Buckley (1996), have ventured to combine some of these perspectives with the aim of providing a more robust account of internationalisation processes. In the IBR special issue on the internationalisation process of the firm, an article by Hadjikhani and Johanson (2002, p. 255) recently suggested that "further studies trying to integrate the two traditions will contribute to our knowledge of the dynamics of internationalisation”. These two traditions are the economic and the behavioural models of internationalisation. The former can be illustrated by the perspective on foreign market entry, while the latter can be illustrated by the perspective on internationalisation and subsidiary development.

In line with these latter works, this article puts forward a framework for analysing internationalisation processes; its aim is to further our understanding of how firms internationalise their operations ${ }^{(1)}$. The framework borrows conceptual notions from the perspectives on foreign market entry, internationalisation processes and subsidiary development. Two definitions are important here. Internationalisation processes are defined as sequences of servicing modes. A servicing mode is, in turn, defined as an institutional (or governance) arrangement through which the firm services foreign markets.

In this article, we are specifically concerned with internationalisation processes of multinationals (MNCs), defined as firms which control at least one foreign subsidiary (Randoy and Dibrell, 2002). Our view is that MNCs can be conceptualised as a differentiated inter-organisational network (Ghoshal and Bartlett, 1990), which implies that their internationalisation processes are explained at the level of relationships (Andersen and Buvik, 2002; Blomstermo, Eriksson 
and Sharma, 2002). This boundary condition means that novices in the international arena are outside the scope of the framework.

Three implications for empirical studies on internationalisation processes are subsequently drawn from the framework. First, we propose that internationalisation processes should be conceptualised in terms of intra and inter-organisational relationships articulated in distinct spatial-temporal contexts. Secondly, truncated and discontinuous internationalisation processes may be as common as incremental ones. This means that internationalisation processes do not necessarily involve gradual patterns of resource commitment over time. Thirdly, the modal shift is not necessarily restricted to the initial foreign market. It may comprise other countries, for example when the focal subsidiary's operations are expanded to geographical areas outside the initial foreign market. In this particular case, we say that the focal subsidiary's operations evolve from what we call locally-bound to supralocal operations.

This article is divided up as follows. In section one, we briefly review the relevant literature by concentrating on the reasons why each theoretical perspective is not well-equipped for dealing with internationalisation processes on its own. Section two introduces the analytical framework. The last section is dedicated to discussing the implications for empirical studies derived from the framework.

\section{Literature ReView}

The first theoretical perspective considered here is called foreign market entry. It has placed emphasis on the initial choice for operating internationally. In doing so, it concentrates on explaining how and why firms choose a particular mode with which to enter a given foreign market. It is suggested that the key factor is costs, in particular transaction costs (Edwards and Buckley, 1998). In some studies transaction costs appear to be the major determinant (e.g. Davidson and McFetridge, 1985; Gatignon and Anderson, 1988), whereas in others their importance diminishes considerably in favour of risk and strategic factors such as global concentration and synergy (e.g. Hill, Hwang and Kim, 1980; Contractor, 1990).

The perspective on foreign market entry has some drawbacks for analysing internationalisation processes, as proposed here. First, it usually implies that the entry mode is always a critical event in the internationalisation of the firm. Frequently, scholars have justified their studies on the assumption that either the initial choice is one of the most challenging decisions faced by firms during 
internationalisation or that the initial mode exerts a critical influence on the subsequent trajectory of the firm in a particular foreign market. Neither of them, however, always holds. The entry mode can, sometimes, be of unimportance for the firm and, therefore, selected fortuitously. Also, the entry into foreign markets may not have a critical impact on the subsequent trajectory (Nieminen and Tornroos, 1997), but this is an open, empirical question rather than an assumption. This has led Bell and Young (1998) to rightly contend that the emphasis on the initial choice has been rather exaggerated.

Secondly, this perspective overemphasises costs at the expense of other factors in determining the entry mode. Madhok (1997), for example, argues that the entry decision essentially involves value creation considerations. Rather than minimising transaction costs, the major concern of the firm is how to develop, coordinate and enhance the utilisation of its capabilities. Foreign market entry is, according to this view, a way of managing capabilities and so appears to be determined by management of value instead of management of costs.

Thirdly, the economic analysis of foreign market entry takes a static snapshot of what is essentially a dynamic phenomenon. As its emphasis is on the reasons why a given mode is selected, it does not account for the process which precedes the selection of the initial mode, nor does it consider its process of evolution.

Finally, this perspective does not pay sufficient attention to actors other than the headquarters (HQ) and the focal subsidiary. The choice of the initial mode is usually regarded as a top-down process driven by the HQ. In this respect, the coordination and interaction amongst subsidiary units within the MNC is not an issue for this perspective (Buckley, 1996).

The second perspective is called here internationalisation and is based on the Uppsala model of internationalisation (Johanson and Wiedersheim-Paul, 1975; Johanson and Vahlne, 1977). The aim of this model is to understand how and why firms enter and develop in a particular foreign market. It has been suggested that the process of internationalisation is gradual, through which firms commit resources to and increase knowledge of a particular foreign market incrementally. Lack of experience in a given foreign market is considered one of the major constraints to the internationalisation of the firm.

Unlike the perspective on foreign market entry, this perspective views the initial choice as a step in a larger, more complex and dynamic process. It is not concerned with structure only, but also with processes. As in the case of the previous perspective, it still gives emphasis to both the HQ and the focal subsidiary as the key actors in the internationalisation of the firm. This means that it does not explicitly consider that internationalisation processes can be affected by other 
actors such as suppliers, buyers and sister subsidiaries (Johanson and Vahlne, 1990).

In addition, this perspective focuses on processes embedded only in the foreign market where the focal subsidiary is initially established. As its operations are viewed as locally-bound, we argue that the Uppsala model may explain internationalisation processes up to the point where the highest resource commitment mode is established in a particular foreign market, usually represented by local manufacturing ${ }^{(2)}$. When the focal subsidiary reaches this stage, the perspective implicitly suggests that the internationalisation of the firm in that foreign market is complete.

The last perspective considered here, subsidiary development, is a very recent spin-off from the literature on MNC management and control, dating back no further than the mid 1990s. Its primary objective is to describe and explain the process of evolution of the subsidiary. According to this perspective, subsidiary is defined as "any operational unit controlled by the MNC and situated outside the home country” (Birkinshaw, 1997, p. 207). The process of development of the subsidiary unit is, in turn, defined as the "growth and enhancement of subsidiary resources and add increasing levels of value to the multinational corporation as a whole” (Birkinshaw, 1998, p. 34). This process is usually described by using value added as an indicator, illustrated along two dimensions (Birkinshaw, 1998): (1) the extent through which the subsidiary undertakes activities in the MNC's value chain; (2) the geographical scope for which the subsidiary is responsible, i.e. local, regional or global activities.

This perspective is considered here to fill the gap left by the perspective on internationalisation, i.e. it takes into account that internationalisation processes do not solely take place in the initial foreign market. Accordingly, a given subsidiary unit can gain a mandate by either internationalising its operations (Forsgren, Holm and Johanson, 1992) or by taking on more responsibilities within the MNC group of which it is part (Birkinshaw, 1996).

Birkinshaw and Hood (1997) contend that this perspective is a natural extension of the internationalisation perspective to the extent that both focus on the process of development of MNCs. Accordingly, the perspective on subsidiary development would start when the perspective on internationalisation ends. By contrast, we claim that the perspective on subsidiary development overlaps with the perspective on internationalisation. It means that whereas the latter takes as its endpoint the establishment of local manufacturing in a particular foreign market, the former takes as its starting point the establishment of operations in that initial foreign market, which does not necessarily mean local manufacturing. More precisely, 
the perspective on subsidiary development embraces situations in which the MNC sets up a sales subsidiary in a foreign market, which is, according to the Uppsala model, an anterior stage to local manufacturing (Johanson and WiedersheimPaul, 1975).

Put another way, the perspective on subsidiary development takes the subsidiary configuration as a given. This point is somewhat troublesome in internationalisation processes as it raises the issue of where the starting point is. It seems that the starting point is not the first experience of the firm in a particular overseas market but the point when the subsidiary is already placed, which is usually represented by a sales subsidiary. However, the perspective on internationalisation also focuses on the sales subsidiary, viewing this mode as an intermediate stage between low and high resource commitment modes (Johanson and Wiedersheim-Paul, 1975). In this sense, it seems to be an overlapping relation between both perspectives, manifested when the firm moves on from sales subsidiary to local manufacturing in a particular foreign market.

Based on this line of reasoning, we argue that the perspective on subsidiary development is not an extension of the perspective on internationalisation, nor should it be regarded in isolation when analysing internationalisation processes. We propose combining it with the aforementioned perspectives on foreign market entry and internationalisation in order to analyse internationalisation processes. Our attempt to borrow concepts from these three perspectives and integrate them into a single framework is developed in the next section.

\section{The Analytical Framework: Levels of Analysis}

The analytical framework proposed here comprises two levels of analysis. The first level refers to the phases of internationalisation processes as well as to the relationships that account for these phases. The second level of the analytical framework is a manifestation of the relations suggested in the first level. It is characterised by an indicator called here the servicing mode, which is a combination of the degree of localisation and externalisation of activities in a foreign market as well as the degree of integration of activities across countries (Jarillo and Martinez, 1991).

\section{The First Level: Phases and Relationships}

The first level of the analytical framework comprises three phases: entry, 
local network trajectory and supra-local network trajectory (see Figure 1). The entry is usually called foreign market entry and refers to the process through which the firm develops relationships with actors located in a particular foreign market. The local network trajectory corresponds to the sequence of servicing modes in that foreign market. We suggest that the firm can follow different sequences. For example, it can enter and subsequently develop in a given foreign market (Johanson and Vahlne, 1977) or alternatively, it can decrease levels of resources to that foreign market (Benito and Welch, 1997; Zander, 1997). In this sense, we do not hold the assumption of unilinear sequences of servicing modes in a given foreign market.

Figure 1: Phases

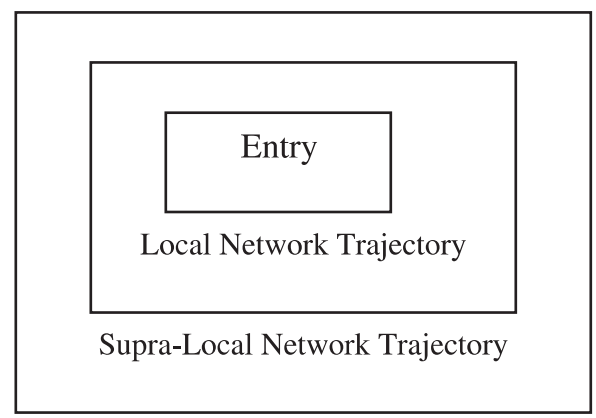

Having followed a particular sequence of servicing modes in the foreign market where it is initially established, the focal subsidiary can also assume responsibilities in other countries (Forsgren, Holm and Johanson, 1992; Birkinshaw, 1996). These countries are usually reached using the initial foreign market as a platform. This process is called here the supra-local network and corresponds to the third phase of the analytical framework.

We also suggest that three types of relationships are important for explaining the three phases discussed earlier. They are the HQ relationships, other subsidiary relationships, and external actor relationships (see Figure 2). The HQ relationships are usually characterised by control over the subsidiary units. However, research on subsidiary development has suggested that the degree of control might vary as a result of the context in which the subsidiary units are embedded (e.g. Paterson and Brock, 2002). In other words, it appears that the degree of HQ control is not similar to all subsidiaries within the MNC group (Holm, Johanson and Thilenius, 1995). 


\section{Figure 2: Relationships}

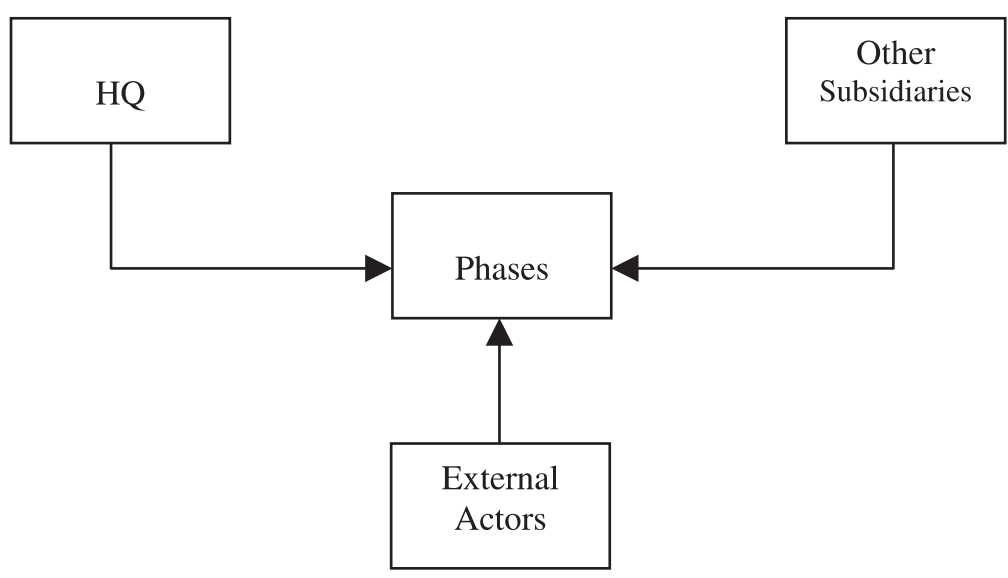

The second type of relationship is that of other subsidiaries. It is considered here because subsidiaries other than the focal one can significantly affect the internationalisation of the firm. As the HQ appears to exert different levels of control over the subsidiary units, powerful subsidiaries, i.e. units that control critical resources within the MNC group, can take on more responsibilities in the MNC, thus influencing the development of sister subsidiaries. Other subsidiaries do not necessarily mean foreign-based units because these units can be geographically embedded in the foreign market where the focal subsidiary is implanted. For example, the firm can establish two or more units in the same foreign market, each one being in charge of a business division.

The third and last type of relationship refers to external actors. External actors are those not directly controlled by the MNC and, therefore, comprise business and non-business organisations such as buyers and suppliers that affect the internationalisation of the firm. As external actors can be geographically embedded in different network contexts, the link with the focal subsidiary is either direct or indirect. For example, the focal subsidiary is directly connected to first-tier suppliers embedded in the foreign market where it is implanted and is indirectly connected to first-tier suppliers' suppliers, possibly embedded in various other network contexts.

\section{The Second Level: the Indicator}

The second level of the analytical framework comprises the indicator through which the relations discussed earlier can be observed. Our discussion is based on the study of Jarillo and Martinez (1991) on international strategy. Broadly, the 
authors suggest characterising an international strategy according to three dimensions (see Figure 3): (1) the degree of externalisation of activities in each country; (2) the degree of localisation of activities in each country; and (3) the degree of integration of activities across different countries.

\section{Figure 3: Three Dimensions of International Strategy}

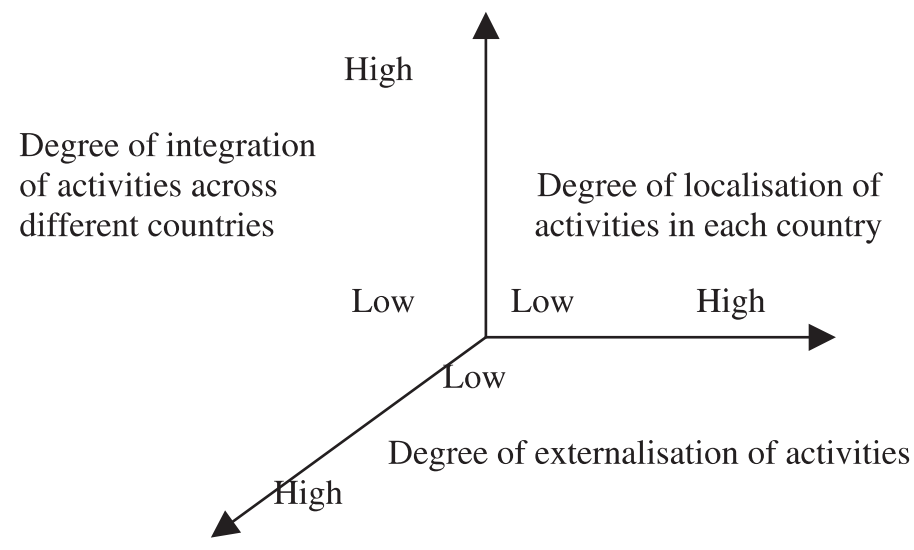

Source: Jarillo and Martinez (1991).

The degree of externalisation of activities refers to the extent to which the MNC performs different activities along the value chain either in-house or through other firms. The degree of localisation of activities means the extent to which the MNC undertakes activities along the value chain in a particular foreign market. The degree of integration of activities corresponds to the degree of co-ordination amongst subsidiary units.

In characterising an MNC's international strategy, Jarillo and Martinez (1991) put forward dimensions that are sensitive to two key issues in relation to the subsidiary unit. First, the degree of externalisation of activities and the degree of localisation of activities are sensitive to changes in the pattern of activities along the value chain of a given subsidiary in the foreign market where it is established. Secondly, the degree of activities across countries is sensitive to changes in the geographical mandate of the subsidiary. As both changes are pivotal to our analytical framework, we have decided to construct our indicator using similar dimensions.

Thus, we suggest that the servicing mode, which is characterised by the degree of integration, localisation and externalisation of activities, is the institutional (or governance) arrangement through which the firm services foreign markets. We 
consider that a new institutional (or governance) arrangement appears if the firm changes at least one of these dimensions. For example, a focal subsidiary servicing only the foreign market in which it is implanted through local manufacturing and whose activities are fully undertaken in-house can broadly be characterised as follows: the degree of integration is low since the subsidiary is not involved with other countries. The degree of localisation is relatively high because the focal subsidiary is involved with manufacturing operations in that foreign market. The degree of externalisation of activities is low because the activities are performed internally. In this case, if the focal subsidiary starts co-ordinating operations at a regional level by managing other subsidiaries' operations, it is assumed here that it has switched the servicing mode by increasing the degree of integration of activities.

In this respect, the servicing mode needs to be analysed longitudinally. It has to be compared with the previous mode because the existing configuration has no meaning unless the temporal and geographical relations are considered. Put differently, rather than a particular structure in a vacuum, our conceptualisation of the servicing mode entails a spatial and time-embedded outcome of a larger and more complex process. It places emphasis on where and when a particular mode is selected as well as where and when the mode is changed. These two aspects are respectively called here modal choice and modal shift.

Summing up, the analytical framework proposed here comprises two levels. The first level embraces three phases (entry, local network trajectory and supralocal network trajectory) as well as three relationships (HQ, other subsidiaries and external actors). It has been suggested that these phases can be explained by these relationships. The second level refers to the indicator through which these relations can be observed. Our indicator is called the servicing mode, and it embraces the following dimensions: the degree of localisation and externalisation of activities in a given foreign market as well as the degree of co-ordination of activities across countries. All these relations are depicted in Figure 4. 


\section{Figure 4: The Analytical Framework}

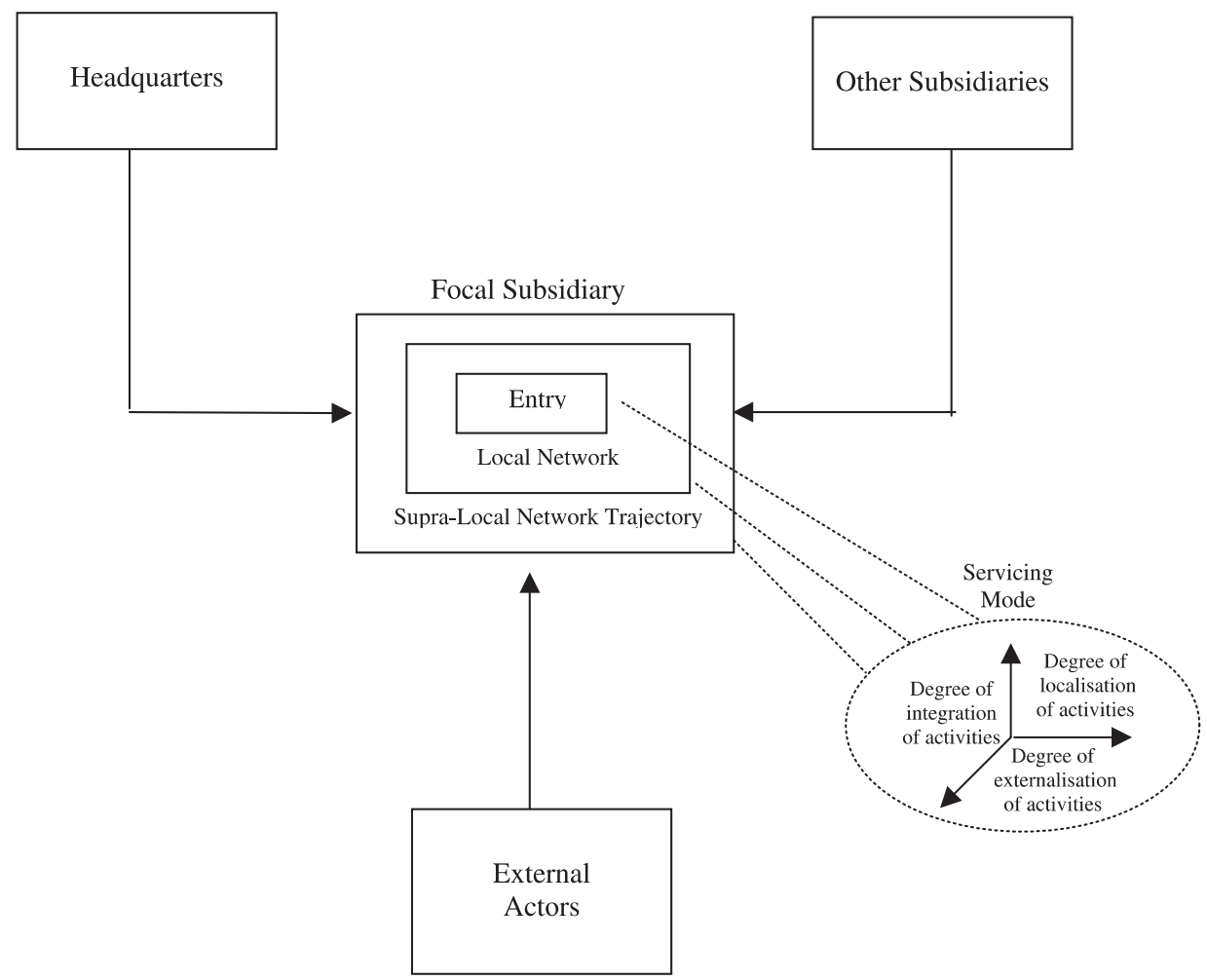

\section{IMPLICATIONS}

Based on the analytical framework discussed in the last section, three implications for empirical studies on internationalisation processes, as we have proposed here, are suggested. The first implication is that internationalisation processes result from intra and inter-organisational relationships articulated in distinct spatialtemporal contexts.

We view the MNC as a network where different units are connected to each other through relationships (Holm, Johanson and Thillenius, 1995). The idea of centreperiphery in which the HQ is the only unit within the MNC group that controls key resources is replaced by a less-hierarchical view of MNCs (Marshan, 1997). This means that the concept of a single centre controlling different units is taken over by the idea of loose coupling in which multiple centres within the MNC group possess important resources and capabilities (Bjorkman and Forsgren, 2000). The evolution 
of the MNC, according to this view, results from the evolution of different actors embedded in distinct, yet overlapping networks (Mattsson, 1998).

In other words, as the MNC appears to be organised in a network-like system (Ghoshal and Bartlett, 1990), it is important to consider its evolution in terms of intra and inter-organisational relationships. On the one hand, intra-organisational relationships have to do with relationships between the HQ and subsidiary units as well as relationships between sister subsidiaries. On the other hand, as each subsidiary unit is embedded in a particular context comprised of different actors such as suppliers and buyers, it is also relevant to focus on relationships between the MNC units and these actors, i.e. on inter-organisational relationships.

The geographical and the historical contexts in which these relationships are embedded play a critical role in understanding internationalisation processes. In relation to the geographical context, actors interact with one another either directly or indirectly and, consequently, produce changes that eventually are transmitted and transformed into different nodes within the MNC group (Easton and Lundgren, 1992). Because these actors are usually embedded in different, yet overlapping networks, changes can be triggered in different parts of the MNC network. Put another way, changes triggered in geographical contexts other than the one where the focal subsidiary is based may have an impact on the sequence of servicing mode. For example, acquisitions carried out in Europe may affect the trajectory of subsidiary units located in Latin America.

Usually the extant literature has placed emphasis on relationships that are activated in the foreign market where the focal subsidiary is embedded. In giving prominence to the geographical context of relationships, our analytical framework entails different relations. Local changes such as changes triggered in the initial foreign market, as well as more distant changes, i.e. changes triggered in foreign markets other than the initial one, may play a role in internationalisation processes. To the best of our knowledge, little has been said about distant changes in internationalisation processes. We believe that this aspect needs to be explored by future research.

Concerning the historical context, our analytical framework proposes that history matters in internationalisation processes. Accordingly, relationships are sometimes activated in a distant period of time from the modal choice. For example, the HQ may establish relationships with external actors embedded in a particular foreign market that do not necessarily involve economic transactions. These relationships may or may not pave the way for the establishment of a particular servicing mode. If they do, the time lag between the establishment of the relationships and the choice of the servicing mode may be long. 
As relationships can be articulated at different times, they are not necessarily exercised simultaneously. A particular relationship can be activated first and subsequently activate other relationships. For example, the HQ initially establishes relationships with external actors, giving rise to a particular servicing mode. Later, this mode evolves by increasing the degree of integration of activities across countries. This means that it is likely to affect the development of sister subsidiaries. In this particular case, the HQ and external actor relationships are activated first. The other subsidiary relationships are involved afterwards.

Although apparently simple, the idea that relationships are highly susceptible to the historical context is particularly important to studies on internationalisation processes. Previous studies, such as those on foreign market entry, usually view the modal choice as being compressed to one event induced by a number of driving forces that operate together and simultaneously. Even some studies that analyse the internationalisation of the firm longitudinally such as Chang and Rosenweig (2001) have implicitly assumed that the forces that drive the MNC to change servicing modes are exercised at the moment of the modal choice. Consequently, it seems that there is a vacuum between modal choices, a space where the driving forces are dormant. By contrast, our framework subscribes to the proposition that relationships that affect the modal choice and change are liable to timing (Blomstermo, Eriksson and Sharma, 2002). What happens at the moment of the modal choice as well as between modal choices are both regarded as critical. Once again, this needs to be examined in detail by further studies on internationalisation processes.

The second implication of our framework refers to the idea of gradualism and discontinuity in internationalisation processes. Although gradual processes have been well given emphasis by the literature, in particular the Uppsala model (Johanson and Vahlne, 1977), our analytical framework paves the way for describing and explaining processes that do not conform to incremental patterns such as the establishment chain. Broadly, it is suggested here that the idea of incremental development in foreign markets as well as unilinear sequences of servicing modes should be de-emphasised in favour of more irregular and truncated trajectories where different patterns of change are common (Turnbull and Ellwood, 1986; Zander, 1997).

More discontinuous processes can be explained by the fact that a particular internationalisation process is embedded in a network of other internationalisation processes. At the points where different processes collide, discontinuities may arise, i.e. a particular internationalisation process may break by taking a different path, the one which does not bear the imprint of the initial choice (Mahoney, 2000). In other words, we suggest that a particular internationalisation process is 
not an autonomous sequence of servicing modes, but is subject to the effect of other sequences of servicing modes. At the points where they meet, internationalisation processes may divert to a different path from the one originally taken $^{(3)}$. In this case, gradual processes are replaced by more discontinuous, truncated processes. It is our contention that explaining the mechanisms that account for these discontinuities should be explored by future research on the internationalisation of the firm.

The third and last implication means that internationalisation processes are neverending phenomena. This is vexingly obvious; however, the theoretical perspectives examined earlier have regarded them as implicitly having an endpoint. The perspective on foreign market entry has focused on the initial mode. The perspective on internationalisation has analysed gradual sequences from the initial choice up to the point where the focal subsidiary establishes the highest resource commitment mode in a particular foreign market. Little has been said in this perspective about what happens to the focal subsidiary after it reaches this stage. The existence of this gap has paved the way for the literature on subsidiary development, which has, in turn, overlooked the initial steps of internationalisation processes.

Our framework proposes that internationalisation processes may involve modal choices and shifts within and beyond the foreign market where the focal subsidiary is originally implanted. The initial as well as the last steps may be equally relevant from a theoretical standpoint. More specifically, the focal subsidiary may be involved only with operations that are geographically bounded to a particular foreign market. This is the case examined by the Uppsala model. Alternatively, the focal subsidiary may extend the geographical scope of its operation by assuming responsibilities in other countries. We call this type of operation supra-local. In this case, the focal subsidiary extends its role in the MNC group by either internationalising operations to other foreign markets or co-ordinating sister subsidiaries.

According to our view, conceptualising internationalisation processes as neverending phenomena may represent an attempt to engage the economic and behavioural models into conversation. Needless to say, this conversation is an important step towards a more comprehensive account of the internationalisation of the firm.

\section{Final Remarks}

This article proposes a framework for analysing internationalisation processes. This framework is an attempt to combine conceptual notions from the perspectives 
on foreign market entry, internationalisation and subsidiary development. In doing so, our aim is to contribute to the advancement of our knowledge of internationalisation processes and, as a result, to offer a number of potential avenues for empirical research.

The framework has two levels of analysis. The first level defines internationalisation processes as sequences of servicing modes and embraces three phases - entry, local network trajectory and supra-local network trajectory - and three relationships that account for these phases - the HQ, external actors and other subsidiaries.

The second level of the framework consists of an indicator through which the phases and relationships are observed. We have chosen the servicing mode, defined here as the institutional (or governance) arrangement through which the firm services foreign markets. The servicing mode is viewed as an outcome of a large and complex course of action. It is characterised by the degree of internationalisation and localisation of activities along the value chain in a particular foreign market as well as the degree of integration of activities across countries.

Three implications for empirical studies have been suggested. First, we argue that a better understanding of internationalisation processes will be achieved if these processes are conceptualised as resulting from intra and inter-organisational relationships articulated in distinct spatial-temporal contexts. It is our claim that the spatial and temporal contexts should explicitly be taken into account by future research on the internationalisation of the firm.

We also contend that the analytical framework proposed here leaves room for internationalisation processes that do not conform to the pattern of changes described by the Uppsala model, i.e. incremental processes. It has been suggested that discontinuities arise because a particular internationalisation process is part of other internationalisation processes embedded in multiple geographical contexts and, therefore, is subject to changes originated and channelled through various relationships connected to the focal subsidiary. This proposition implies that future research should probe the mechanisms that account for these irregular patterns.

Finally, it is our contention that analysing sequences of servicing modes should take into account modal choices and shifts that embrace the foreign market where the subsidiary is implanted as well as other markets reached from that foreign market. In doing so, we will be paving the way for establishing a dialogue between the economic and behavioural models of the internationalisation of the firm. 


\title{
Notes
}

\begin{abstract}
${ }^{1}$ An earlier version of this article was presented at the XXVI ENANPAD and short-listed for the best paper of the international management track. We appreciate the comments of the conference participants, in particular those of Suzana Braga Rodrigues. We are also grateful to Angela Versiani, Luis Araujo and Roberto Gonzalez Duarte for their advice and comments on early drafts of this article. Special thanks to CAPES for having financially supported the research that underpinned this article. All errors are mine.

${ }^{2}$ This is illustrated by the concept of the establishment chain, which comprises four stages from low to high resource commitment modes: no regular export activities, export via independent representatives, sales subsidiaries and eventually local manufacturing (Johanson and Wiedersheim-Paul, 1975).

${ }^{3}$ This discussion is inspired by the notion of path dependence (e.g. Arthur, 1994; Mahoney, 2000).
\end{abstract}

\section{References}

\section{ABBOTT, A.}

Time matters: on theory and method. Chicago: The University of Chicago Press, 2001.

\section{ANDERSEN, O;}

BUVIK, A.

Firms' internationalization and alternative approaches to the international customer/market selection. International Business Review, v. 11, p. 347363, 2002.

ANDERSON, E.; GATIGNON, H.

Modes of foreign entry: a transaction cost analysis and propositions. Journal of International Business Studies, v. 17, n. 3, p. 1-26, 1996.
ARTHUR, W. B.

Increasing returns and path dependence in the economy. Ann Arbor: University of Michigan Press, 1994.

\section{BELL, J.;}

YOUNG, S.

Towards an integrative framework of the internationalization of the firm. In: HOOLEY, G.; LOVERIDGE, R.; WILSON, D. (Eds.). Internationalization: process, context and markets. New York: MacMillan, 1998. p. 5-28.

BENITO, G;

WELCH, L.

De-Internationalization. Management International Review, v. 37, n. 2, p. 7-25, Special Issue 1997. 
BIRKINSHAW, J.

How multinational subsidiary mandates are gained or lost. Journal of International Business Studies, p. 467-495, Third Quarter 1996.

Entrepreneurship in multinational corporations: the characteristics of subsidiary initiatives. Strategic Management Journal, v. 18, p. 207-229, 1997.

Foreign-owned subsidiaries and regional development: the case of Sweden. In: BIRKINSHAW, J.; HOOD, N. (Eds.). Multinational corporate evolution and subsidiary development. New York: MacMillan, 1998. p. 268-298.

BIRKINSHAW, J.; HOOD, N.

An empirical study of development processes in foreign-owned subsidiaries in Canada and Scotland. Management International Review, v. 37, n. 4, p. 339-364, 1997.

BJORKMAN, I.; FORSGREN, M.

Nordic international research: a review of its development. International Studies of Management and Organization, v. 30, n. 2, p. 362-376, 2000.

BLOMSTERMO, A.;

ERIKSSON, K.;

SHARMA, D.

Knowledge and time: a forgotten factor in the internationalisation process of firms. In: HAVILA, V.; FORSGREN, M.; HAKANSSON, H. (Eds.). Critical perspectives on internationalization. Oxford: Pergamon, 2002. p. 263-283.

\section{BUCKLEY, P.}

The role of management in international business theory: a meta-analysis and integration of the literature on international business and international management. Management International Review, v. 36, n. 1, p. 7-54, Special Issue 1996.

\section{BUCKLEY, P.;}

\section{CASSON, M.}

Models of multinational enterprise. Journal of International Business Studies, v. 29, n. 1, p. 21-44, 1998a.

Analysing foreign market entry strategies: extending the internalization approach. Journal of International Business Studies, v. 29, n. 3, p. 539-562, 1998b.

\section{CHANG. S.;}

ROSENZWEIG, P.

The choice of entry mode in sequential foreign direct investment. Strategic Management Journal, v. 22, p. 747-776, 2001. 
CONTRACTOR, F.

Contractual and cooperative forms of international business: towards a unified theory of modal choice. Management International Review, v. 30, n. 1, p. 31-54, 1990.

DAVIDSON, W.;

MCFETRIDGE, D.

Key characteristics in the choice of international technology transfer mode. Journal of International Business Studies, v. 16, n. 2, p. 5-22, 1985.

DUNNING, J. H.

Reappraising the eclectic paradigm in an age of alliance capitalism. In: COLOMBO, M. C. (Ed.). The changing boundaries of the firm: explaining evolving inter-firm relations. London: Routledge, 1998. p. 29-59.

EASTON, G.;

LUNDGREN, A.

Changes in industrial networks as flow through nodes. In: AXELSSON, B.; EASTON, G. (Eds.). Industrial networks: a new view of reality. London: Routledge, 1992. p. 88-104.

EDWARDS, R.;

BUCKLEY, P.

Choice of location and mode: the case of Australian investors in the UK. International Business Review, v. 7, p. 503-520, 1998.
FORSGREN, M.

Managing the internationalization process: the Swedish case. London: Routledge, 1989.

FORSGREN, M.;

HOLM, U.;

JOHANSON. J.

Internationalization of the second degree: the emergence of European-based centers in Swedish firms. In: YOUNG. S.; HAMIT, J. (Eds.). Europe and the multinationals. Hants: Edward Elgar, 1992. p. 235-253.

FORSGREN, M.;

JOHANSON, J.

Managing internationalization in business networks. In: FORSGREN, M.; JOHANSON, J. (Eds.). Managing networks in international business. Philadelphia: Penn, Gordon and Breach, 1992. p. 1-16.

GATIGNON, H.; ANDERSON, E.

The multinational corporation's degree of control over foreign subsidiaries: an empirical test of a transaction cost explanation. Journal of Law, Economics and Organization, v. 4, n. 2, p. 305336, 1988. 
GHOSHAL, S.;

BARTLETT, C.

The multinational corporation as an interorganizational network. Academy of Management Review, v. 5, n. 4, p. 603-625, 1990.

\section{HADJIKHANI, A;} JOHANSON, J.

\section{Editorial. International}

Business Review, v. 11, p. 253255, Special Issue 2002.

\section{HILL, C.; \\ HWANG, P.; \\ KIM, W.}

An eclectic theory of the choice of international entry mode. Strategic Management Journal, v. 11, p. 117-128, 1980.

HOLM, U.; JOHANSON, J.; THILENIUS, P.

Headquarters' knowledge of subsidiary network contexts in the multinational corporation.

International Studies of Management and Organization, v. 25, n. 1-2, p. 97119, 1995.

JARILLO, J.;

MARTINEZ, J.

The international expansion of Spanish firms: towards an integrative framework for international strategy. In:
MATTSSON, L-G.; STYMNE, B. (Eds.). Corporate and industry strategies for Europe. Amsterdam: Elsevier Science Publishers, 1991. p. 282-302.

\section{JOHANSON, J.;}

VAHLNE, J-E.

The internationalization process of the firm: a model of knowledge development and increasing foreign market commitment. Journal of International Business Studies, v. 8, n. 1, p. 23-32, 1977.

The mechanism of internationalisation. International Marketing Review, v. 7, n. 4, p. 11-24, 1990.

JOHANSON, J.; WIEDERSHEIM-PAUL, F.

The internationalization of the firm: four Swedish case. Journal of Management Studies, p. 305322, Oct. 1975.

\section{MADHOK, A.}

Cost, value and foreign market entry mode: the transaction and the firm. Strategic Management Journal, v. 18, p. 39-61, 1997.

\section{MAHONEY, J.}

Path dependence in historical sociology. Theory and Society, v. 29, p. 507-548, 2000. 
MARSCHAN, R.

Dimensions of less-hierarchical structures in multinationals. In: BJORKMAN, I.; FORSGREN, $M$. (Eds.). The nature of the international firm: Nordic contribution to international business research. Copenhagen: Copenhagen Business School Press, 1997. p. 433-450.

\section{MATTSSON, L-G.}

Dynamics of overlapping networks and strategic actions by the international firm. In: CHANDLER, A.; HAGSTROM, P.; SOLVELL, O. (Eds.). The dynamic firm: the role of technology, strategy, organization, and regions. Oxford: Oxford University Press, 1998. p. 242259.

NIEMINEN, J.;

TORNROOS, J-A.

The role of learning in the evolution business network in Estonia: four finnish case studies. In: BJORKMAN, I.; FORSGREN, $M$. (Eds.). The nature of the international firm: Nordic contribution to international business research. Copenhagen: Copenhagen Business School Press, 1997. p. 189-229.
PATERSON, S.;

BROCK, D.

The development of subsidiarymanagement research: review and theoretical analysis. International Business Review, v. 11, p. 139163, 2002.

RANDOY, T.;

DIBRELL, C. C.

How and why Norwegian MNCs commit resources abroad: beyond choice of entry mode. Management International Review, v. 42, p. 119-140, 2002.

TURNBULL, P.; ELLWOOD, S.

Internationalisation in the information technology industry. In: TURNBULL, P.; PALIWODA, S. (Eds.). Research in international marketing. Great Britain: Croon Helm, 1986. p. 172-185.

\section{ZANDER, I.}

The Tortoise evolution of the multinational corporation: foreign technology activity in Swedish multinational firms 18901990. Stockholm: Stockholm School of Economics, 1997. 